\title{
Antimicrobial activity of crude extracts from actinomycetes against mastitis pathogens
}

\author{
R. F. Leite, ${ }^{*}$ J. L. Gonçalves, ${ }^{*}$ A. P. F. Peti,† F. S. Figueiró,† L. A. B. Moraes,† and M. V. Santos*1 \\ *Department of Animal Sciences, School of Veterinary Medicine and Animal Sciences, University of São Paulo (USP), Pirassununga, SP, Brazil, \\ $13635-900$ \\ †Department of Chemistry, University of São Paulo (USP), Ribeirão Preto, SP, Brazil, 14040-901
}

\begin{abstract}
The emergence of antimicrobial resistance to commonly used antibiotics has necessitated the development of new antimicrobial products. Crude extracts produced by actinomycetes contain antimicrobial metabolites that can inhibit bacterial growth. The objective of our study was to evaluate the antimicrobial activity of crude extracts (Caat1-54 and CaatP5-8) produced by actinomycetes against isolates of Staphylococcus aureus, Staphylococcus chromogenes, Streptococcus dysgalactiae, and Streptococcus uberis, which were obtained from the milk of cows affected by mastitis in 23 dairy herds. Twenty isolates of each bacterial species were used to define minimum inhibitory concentrations (MIC) of both crude extracts and ceftiofur (positive control). The $\mathrm{MIC}_{50}$ and $\mathrm{MIC}_{90}$ were defined at the concentration required to inhibit the growth of 50 and $90 \%$ of bacterial isolates tested, respectively. The MIC results were evaluated by survival analysis. Staphylococcus aureus isolates presented $\mathrm{MIC}_{90}$ of Caat 1-54 $\geq 6.25 \mu \mathrm{g} / \mathrm{mL}$, ceftiofur $\geq 12.5 \mu \mathrm{g} / \mathrm{mL}$, and Caat P5-8 $\geq 100 \mu \mathrm{g} / \mathrm{mL}$. Streptococcus uberis presented $\mathrm{MIC}_{90}$ of ceftiofur $\geq 0.39 \mu \mathrm{g} / \mathrm{mL}$, Caat $1-54 \geq 50 \mu \mathrm{g} / \mathrm{mL}$, and Caat P5-8 $\geq 100 \mu \mathrm{g} / \mathrm{mL}$. Staphylococcus chromogenes isolated from subclinical mastitis presented $\mathrm{MIC}_{90}$ of Caat $1-54 \geq 0.78 \mu \mathrm{g} / \mathrm{mL}$ and ceftiofur and Caat P5-8 of $\geq 6.25$ and $\geq 100 \mu \mathrm{g} / \mathrm{mL}$, respectively. Streptococcus dysgalactiae isolated from clinical mastitis presented similar $\mathrm{MIC}_{90}$ values between antimicrobials tested (ceftiofur, Caat 1-54, and Caat P-58), but these values $(\geq 100 \mu \mathrm{g} / \mathrm{mL})$ were higher than the values obtained from other pathogens evaluated in the present study. Our results indicate that Caat 1-54 and Caat P5-8 crude extracts present in vitro antimicrobial activity against isolates of Staph. aureus, Staph. chromogenes, Strep. dysgalactiae, and Strep. uberis isolated from clinical and subclinical mastitis.
\end{abstract}

Received January 15, 2018.

Accepted June 23, 2018.

${ }^{1}$ Corresponding author: mveiga@usp.br
Key words: intramammary infection, mastitis pathogen, antimicrobial, minimum inhibitory concentration

\section{INTRODUCTION}

Bovine mastitis is one of the most common infectious diseases in dairy herds, and bacterial infections are the main cause of mastitis (Pol and Ruegg, 2007a). Staphylococcus spp. and Streptococcus spp. are the most frequently isolated bacterial genera causing IMI (Makovec and Ruegg, 2003). Thus, besides economic losses associated with reduced milk production in cases of subclinical mastitis, some costs are associated with antibiotic treatment and disposal of milk with antibiotic residues in cases of clinical mastitis (Rajala-Schultz et al., 2004; Schukken et al., 2009).

The use of antibiotics for mastitis treatment can increase the risk of antimicrobial resistance and reduce efficacy of antibiotic treatments in affected cows (Barkema et al., 2006; Oliveira et al., 2012; Saini et al., 2012). Furthermore, contact between cattle and humans in livestock and the role of animals as a reservoir and source of antimicrobial-resistant bacteria are also a concern to human health (Pol and Ruegg, 2007b; Fitzgerald, 2012).

Most Staphylococcus aureus isolates obtained from bovine mastitis cases were resistant to penicillin, ampicillin, and erythromycin (Jagielski et al., 2014; Liu et al., 2017), whereas Streptococcus dysgalactiae isolates have presented high frequency of resistance to kanamycin, sulfonamide, and streptomycin (Zhang et al., 2018). On the other hand, isolates of Staph. aureus, CNS, and Streptococcus spp. presented low resistance frequency to different classes of antimicrobials commonly used in mastitis treatments (Ruegg et al., 2015; Schmidt et al., 2015). These results were obtained by studies developed in different regions of the world and this divergence may be related to antimicrobial usage. Therefore, periodic monitoring of the susceptibility of mastitis pathogens to commonly used antimicrobials and the effectiveness of new active compounds with 
antimicrobial activity should be done to reduce treatment failures and cross-resistance to human pathogens.

Monitoring antimicrobial resistance can be done by in vitro susceptibility tests such as the disk diffusion method, standard broth dilution (macrodilution and microdilution), and agar dilution techniques (CLSI, 2008). Minimum inhibitory concentration by broth microdilution is a quantitative technique whose results indicate the potential of an antimicrobial to inhibit bacterial growth (Cortinhas et al., 2013).

Most active antimicrobial compounds are produced using biological fermentation. Similarly, the fermentation of actinomycetes, especially Streptomyces, produces crude extracts composed of several metabolites that have antimicrobial activity (Taddei et al., 2006; Chater et al., 2010). Previous studies reported antimicrobial activity of metabolites produced by actinomycetes against human pathogens (bacteria, fungi, and viruses; de Oliveira et al., 2010; Rakshanya et al., 2011; Priya et al., 2015). However, few studies evaluated antimicrobial activity of metabolites produced by actinomycetes against bovine mastitis pathogens. Our hypothesis was that crude extracts obtained from actinobacteria could inhibit growth of mastitis pathogens in vitro. Therefore, the objective of our study was to evaluate antimicrobial activity, using MIC, of 2 crude extracts (Caat 1-54 and Caat P5-8) from actinomycetes against Staphylococcus aureus, Staphylococcus chromogenes, Streptococcus dysgalactiae, and Streptococcus uberis isolates from clinical and subclinical mastitis.

\section{MATERIALS AND METHODS}

\section{Crude Extracts Production and Active Compound Identification}

Actinomycetes used in our study were provided from the bacterial strain collection of Brazilian Agricultural Research Corporation (Coleção de Microrganismos de Importância Agrícola e Ambiental, CCMA, EMBRAPA, Brazil). Strains were maintained as suspensions of mycelia fragments in $20 \%$ glycerol at $-20^{\circ} \mathrm{C}$ and reactivated onto plates containing potato dextrose agar medium at $30^{\circ} \mathrm{C}$. To obtain crude extracts, actinomycetes named Caat 1-54 and Caat P5-8 were cultivated in $500-\mathrm{mL}$ Erlenmeyer flasks containing $100 \mathrm{~mL}$ of potato dextrose medium at $30^{\circ} \mathrm{C}$ under shaking conditions at $150 \mathrm{rpm}$ for $10 \mathrm{~d}$. Both crude extracts, Caat 1-54 and Caat P5-8, were submitted to the same purification process. The isolate Caat 1-54 was inoculated in $4.5 \mathrm{~L}$ of yeast extract-malt extract medium (ISP2) and, after $10 \mathrm{~d}$, the broth fermentation was submitted to liquidliquid extraction with ethyl acetate (Bauermeister et al., 2016). A total of $240 \mathrm{mg}$ of crude extract was puri- fied using a preparative LC with UV detection with a binary pump (Shimadzu Corp., Kyoto, Japan). The following conditions were used: (1) phase A was a gradient of $0.1 \%$ formic acid; (2) phase B was methanol $/ 0.1 \%$ formic acid; (3) gradient started with $70 \%$ phase B, increased linearly to $95 \%$ within $40 \mathrm{~min}$, followed by additional hold for 10 min in $95 \%$ phase B with a flow rate of $16 \mathrm{~mL} / \mathrm{min}$ and detection at 280 and $310 \mathrm{~nm}$; and (4) peak purification was done using a Shim-Pack C18 column (Shimadzu Corp.) $19.0 \times 250$ mm, $10 \mu \mathrm{m}$.

Both crude extracts were fractionated in preparative HPLC. Each fraction was bioassayed against 2 strain identified biochemically as Staph. aureus and analyzed by direct infusion-MS to identify the chemical profile. For this bioassay, $2 \mathrm{~mL}$ of each fraction was dried and solubilized in $10 \mu \mathrm{L}$ of methanol. An aliquot of $5 \mu \mathrm{L}$ was then applied to a thin-layer chromatography plate that was not subjected to the chromatographic process. The thin-layer chromatography plates were covered with potato dextrose agar medium and, after $24 \mathrm{~h}$, a bacterial suspension at a turbidity of 0.5 McFarland standard was spread over the top of the thin-layer chromatography plates containing the medium. Inhibition zones were verified using MTT (thiazolyl blue tetrazolium bromide; Sigma-Aldrich, Saint Louis, MO) staining after $24 \mathrm{~h}$ of bacteria incubation.

\section{Identification of Bacterial Species}

Twenty isolates from each type of pathogen (Staph. aureus, Staph. chromogenes, Strep. dysgalactiae, and Strep. uberis) were obtained from milk samples of mammary quarters $(\mathrm{n}=80)$ of cows affected by mastitis. These cows were distributed in commercial dairy herds $(\mathrm{n}=23)$ in São Paulo and Minas Gerais (southeast Brazil). Milk samples were submitted to microbiological procedures as described in the National Mastitis Council guidelines (Hogan et al., 1999). Staphylococcus aureus isolates were obtained from cases of clinical ( $\mathrm{n}=10 ; 10$ herds) and subclinical $(\mathrm{n}=10 ; 9$ herds $)$ mastitis, whereas Staph. chromogenes $(\mathrm{n}=20 ; 7$ herds) were obtained from cases of subclinical mastitis. Furthermore, Strep. dysgalactiae ( $\mathrm{n}=20 ; 8$ herds) were obtained from cows affected by clinical mastitis and Strep. uberis were isolated from both clinical $(\mathrm{n}=10$; 6 herds) and subclinical ( $\mathrm{n}=10 ; 5$ herds) mastitis. All isolates were identified at the species level using matrix-assisted laser desorption/ionization-time-offlight (MALDI-TOF)-MS (Bruker Daltonik GmbH, Bremen, Germany) coupled with Biotyper Real Time Classification 3.0 software (Bruker Daltonik GmbH), as described by Barreiro et al. (2010). Thus, in the present study, only isolates with species identification score $\geq 2$ were used (Barreiro et al., 2010). After MS 
analysis, isolates were cryopreserved at $-80^{\circ} \mathrm{C}$ in brain heart infusion broth (Becton, Dickinson and Company, Franklin Lakes, NJ) with $20 \%$ glycerol.

\section{Evaluation of Antimicrobial Activity of Crude Extracts}

Minimum inhibitory concentration of crude extracts (Caat 1-54 and Caat P5-8) was determined by broth microdilution technique. Ceftiofur hydrochloride (Sigma-Aldrich) was used as positive control. A sterile microdilution 96-well plate (Cral, Cotia, Brazil) was used for each pathogen (CLSI, 2008). Cryopreserved isolates were retrieved and plated in agar supplemented with $5 \%$ bovine blood. After $24 \mathrm{~h}$ of incubation at $37^{\circ} \mathrm{C}$, catalase and morphological analysis were performed to check bacterial characteristics. Isolates were then incubated at $37^{\circ} \mathrm{C}$ for $24 \mathrm{~h}$ in brain heart infusion broth (Becton, Dickinson and Company). Afterward, bacterial suspensions were standardized to 0.5 McFarland using a nephelometer (Uniscience, São Paulo, Brazil) in $0.9 \%$ saline solution.

In the present study, cation-adjusted Mueller Hinton broth (Becton, Dickinson and Company) had a $\mathrm{pH}$ ranging from 7.2 to 7.4 (CLSI, 2008). Additionally, Mueller Hinton broth was supplemented with $5 \%$ of equine serum for the growing of Streptococcus spp. (CLSI, 2008; Perini et al., 2014). In a 96-well plate, 4 wells were used for broth sterility control and to evaluate growth of isolates. Twenty isolates of each mastitis pathogen (Staph. aureus, Staph. chromogenes, Strep. dysgalactiae, and Strep. uberis) were used for MIC determination of crude extracts from actinomycetes and Staph. aureus ATCC 29213 was used as quality control. Analyses were performed in duplicate.

In the first column of the plate, $15 \mu \mathrm{L}$ of each antimicrobial and $135 \mu \mathrm{L}$ of Mueller Hinton broth were applied to each well, resulting in a final concentration of $100 \mu \mathrm{g} / \mathrm{mL}$ of each antimicrobial. In the other columns, except for control wells, $75 \mu \mathrm{L}$ of Mueller Hinton broth was applied. Serial dilutions were done by transferring $75 \mu \mathrm{L}$ from the first column to the second. After second column homogenization, $75 \mu \mathrm{L}$ was transferred from this column to the third and so on. Therefore, 12 different serial dilutions of each crude extract (Caat 1-54 and Caat P5-8) and ceftiofur (positive control) were obtained. The resulting concentrations ranged from 0.048 to $100 \mu \mathrm{g} / \mathrm{mL}$. After antimicrobial dilution, $7.5 \mu \mathrm{L}$ of each standardized bacterial suspension was applied to wells. The plates were covered with a plastic film and homogenized at $200 \mathrm{rpm}$ for $10 \mathrm{~min}$ on a stirring table (Quimis, Diadema, Brazil). The plates were then incubated at $37^{\circ} \mathrm{C}$ for $24 \mathrm{~h}$ under aerobic conditions. Afterward, $20 \mu \mathrm{L}$ of MTT was added to the plates, homogenized on a stirring table at $200 \mathrm{rpm}$ for $10 \mathrm{~min}$, and packed in silver foil. Briefly, the MTT was used to better visualize bacterial growth and determine MIC values (Shi et al., 2007). After $3 \mathrm{~h}$ of reaction, plates were evaluated by visual inspection and the lowest antimicrobial concentrations that inhibited growth of mastitis pathogens were determined. The ceftiofur breakpoints were used to classify isolates causing bovine mastitis as susceptible $\leq 2 \mu \mathrm{g} / \mathrm{mL}$, intermediate between $>2$ and $<8 \mu \mathrm{g} / \mathrm{mL}$, or resistant $\geq 8 \mu \mathrm{g} / \mathrm{mL}$ in accordance with the guidelines in CLSI document M31A3 (CLSI, 2008); these breakpoints were also used to classify Staph. chromogenes isolates (Cortinhas et al., 2013).

\section{Statistical Analysis}

The $\mathrm{MIC}_{50}$ and $\mathrm{MIC}_{90}$ of Caat 1-54 and Caat P5-8 were determined at the lowest concentration of crude extracts needed to inhibit 50 and 90\%, respectively, of tested isolates of each bacterial species. Survival analysis was performed to evaluate the differences between antimicrobials tested against bacterial isolates, in accordance with procedures done by Cortinhas et al. (2013), by PROC LIFETEST (SAS ver. 9.4, SAS Institute Inc., Cary, NC). Thus, antimicrobial concentrations (Caat 1-54, Caat P5-8, and ceftiofur) were used as time variable and inhibition of bacterial growth was used as event. When isolates were not inhibited at the highest concentration of antimicrobial tested $(100 \mu \mathrm{g} /$ $\mathrm{mL}$ ), they were considered resistant and these isolates were censored by statistical modeling. Antimicrobial concentration was defined as time variable, whereas the null hypothesis of no difference in the survival strata (antimicrobial concentration at inhibition) was tested via log-rank and Wilcoxon tests, in Kaplan-Meier curves. Any $P$-values $<0.05$ were considered significant.

\section{RESULTS}

The active fractions of Caat $1-54$ and Caat $\mathrm{P} 5-8$ produced by actinomycetes exhibited notable antimicrobial activity against gram-positive mastitis pathogens after HPLC and spectroscopic analyses. Direct infusion-MS analyses detected the most active fractions $(\mathbf{F r})$ of Caat 1-54, which ranged from Fr32 to Fr35, whereas for Caat P5-8 the range was from Fr13 to Fr14. The Caat 1-54 active fractions were grouped and Lysolipin I was detected (Figure 1a) by high-resolution mass spectrometry, heteronuclear multiple bond correlation, heteronuclear multiple-quantum correlation, and nuclear magnetic resonance analysis. The Caat P5-8 active fractions were grouped and the active compound (Figure 1b) was assigned to kalafungin structure based on nuclear magnetic resonance, heteronuclear multiple 
<smiles></smiles>

b<smiles>CC1OC2CC(=O)OC2C2=C1C(=O)c1c(O)cccc1C2=O</smiles>

Figure 1. Active compounds identified from crude extracts (Caat 1-54 and Caat P5-8) produced by actinomycetes. Chemical structure of (a) lysolipin I in Caat 1-54 crude extract; and (b) kalafungin in Caat P5-8 crude extract.

bond correlation, heteronuclear single-quantum correlation, and MS/MS fragmentation patterned experiments.

The Caat 1-54 crude extract inhibited $90 \%$ of Staph. aureus $\left(\mathrm{MIC}_{90} \geq 6.25 \mu \mathrm{g} / \mathrm{mL}\right)$, Staph. chromogenes $\left(\mathrm{MIC}_{90} \geq 0.78 \mu \mathrm{g} / \mathrm{mL}\right)$, Strep. dysgalactiae $\left(\mathrm{MIC}_{90} \geq 100\right.$ $\mu \mathrm{g} / \mathrm{mL}$ ), and Strep. uberis $\left(\mathrm{MIC}_{90} \geq 50 \mu \mathrm{g} / \mathrm{mL}\right.$ ) in different concentrations (Table 1). Heterogeneous KaplanMeier survival curves (Figure 2) were observed among these bacterial species $(P<0.0012$ for log-rank test and $P<0.0017$ for Wilcoxon test).

The Caat P5-8 inhibited mostly in 3 consecutive serial concentrations ranging from 25 to $100 \mu \mathrm{g} / \mathrm{mL}$ against all evaluated isolates (Table 1). Briefly, Staph. aureus, Staph. chromogenes, and Strep. uberis had $\mathrm{MIC}_{90} \geq 100 \mu \mathrm{g} / \mathrm{mL}$, whereas Strep. dysgalactiae presented $\mathrm{MIC}_{90}>100 \mu \mathrm{g} / \mathrm{mL}$. Survival curves (Figure 3) were heterogeneous among the 4 species bioassayed ( $P$ $<0.001$ for log-rank and Wilcoxon tests).

Ceftiofur inhibited Staph. aureus, Staph. chromogenes, and Strep. uberis isolates at $\mathrm{MIC}_{90}$ concentrations of $\geq 12.5, \geq 6.25$, and $\geq 0.39 \mu \mathrm{g} / \mathrm{mL}$, respectively (Table $1)$. For Strep. dysgalactiae it was observed that $90 \%$ of isolates presented bacterial growth at the highest concentration analyzed; therefore, $\mathrm{MIC}_{90}$ was $>100 \mu \mathrm{g} /$ $\mathrm{mL}$ (Table 1). These different proportions of inhibition resulted in heterogeneous (Figure 4$)$ survival curves $(P$ $<0.001$ for log-rank and Wilcoxon tests).
The quality control strain Staph. aureus ATCC 29213 presented a MIC value of $1.56 \mu \mathrm{g} / \mathrm{mL}$ for ceftiofur, which is somewhat above the recommended CLSIacceptable quality control ranges $(0.25,0.50$, and 1.0 $\mu \mathrm{g} / \mathrm{mL}$; CLSI, 2008). Therefore, the MIC value of 1.56 $\mu \mathrm{g} / \mathrm{mL}$ obtained for ceftiofur in the current study could have been similar if the same breakpoints of CLSI had been adopted.

According to the evaluation of susceptibility of mastitis pathogens to ceftiofur, $80 \%$ of Staph. aureus isolates were classified as intermediate and $20 \%$ were resistant, whereas for Staph. chromogenes $97.5 \%$ of isolates were classified as intermediate and $2.5 \%$ as resistant. In relation to Streptococcus spp., $80.5 \%$ of Strep. dysgalactiae isolates were considered susceptible and $20 \%$ were resistant whereas $95 \%$ of Strep. uberis isolates were susceptible and $5 \%$ resistant to ceftiofur.

\section{DISCUSSION}

In the present study, we evaluated in vitro antimicrobial activity of crude extracts (Caat 1-54 and Caat P5-8) produced by actinomycetes isolated from the Caatinga biome, which is in northeast Brazil, against mastitis pathogens. Therefore, $\mathrm{MIC}_{50}$ and $\mathrm{MIC}_{90}$ crude extracts were determined in vitro against Staph. aureus, Staph. chromogenes, Strep. dysgalactiae, and Strep. uberis isolated from cows affected by clinical and subclinical mastitis. We observed that Caat 1-54 and Caat P $5-8$ presented antimicrobial activity due to the active compounds lysolipin I (Drautz et al., 1975) and kalafungin (Kakinuma et al., 1990), respectively, against isolates of Staph. aureus, Staph. chromogenes, Strep. dysgalactiae, and Strep. uberis. The Caat 1-54 crude extract presented antimicrobial activity against Staph. aureus, Staph. chromogenes, Strep. dysgalactiae, and Strep. uberis at lower concentrations than Caat P5-8 extract.

The Caat 1-54 extract presented lower values of $\mathrm{MIC}_{50}$ and $\mathrm{MIC}_{90}$ for Staph. aureus than ceftiofur and Caat P5-8 extract. Although Caat 1-54 presented higher inhibition of Staph. aureus, this extract presented higher variability of MIC values because 8 tested dilutions were necessary to inhibit all isolates of Staph. aureus (MIC of Caat $1-54$ between $\geq 0.096$ and $\geq 12.5 \mu \mathrm{g} /$ $\mathrm{mL}$ for clinical and subclinical cases). This variability of MIC values for the inhibition of Staph. aureus may be associated with genetic differences among strains, as the isolates were obtained from different herds and some studies have already reported a great diversity in Staph. aureus population (Smith et al., 2005; Costa et al., 2012). On the other hand, ceftiofur and Caat P5-8 extract presented higher concentrations than Caat 1-54 
LEITE ET AL.

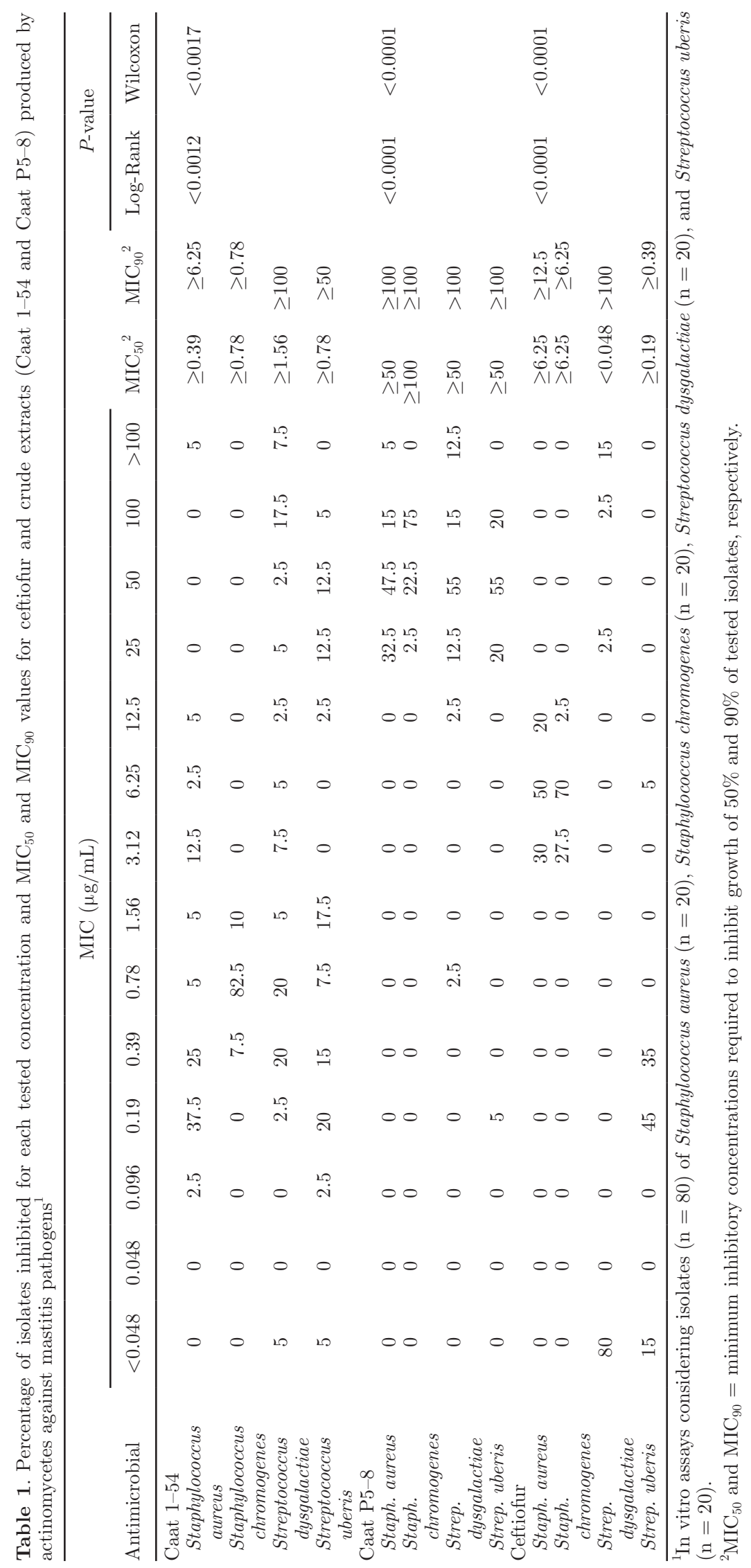


to inhibit Staph. aureus, and only 3 consecutive serial dilutions for inhibition Staph. aureus growth (MIC of ceftiofur between $\geq 3.12$ and $\geq 12.5 \mu \mathrm{g} / \mathrm{mL}$, and MIC of Caat P $5-8$ between $\geq 25$ and $\geq 100 \mu \mathrm{g} / \mathrm{mL}$, clinical and subclinical cases).

Few studies have evaluated the antimicrobial activity of crude extracts produced by actinomycetes against mastitis pathogens. Active metabolites produced by 2 actinomycetes from Amazonia (Streptomyces spp. DPUA 1542 and Nocardia spp. DPUA 1571) presented antimicrobial activity against Staph. aureus isolated from bovine mastitis (Cunha et al., 2010). However, it was difficult to compare the results obtained by Cunha et al. (2010) with the results obtained in the present study because the former used the disk diffusion method. In the present study, we used the microdilution technique because it provides quantitative results (CLSI, 2008).

Due to the concern regarding bacterial resistance and therapy failures, some studies (Diaz et al., 2010; Perini et al., 2014) performed initial trials to evaluate in vitro antimicrobial activity of antimicrobial compounds against pathogens. Among alternatives, essential oils and plants extract have been evaluated most. Diaz et al. (2010) evaluated antimicrobial activity of extracts obtained from medicinal plants used in Brazil against 15 Staph. aureus isolated from bovine mastitis. Thirtyseven extracts were evaluated and 4 of these extracts were observed to inhibited Staph. aureus growth. Cymbopogon nardus extract presented MIC value of $500 \mu \mathrm{g} /$ $\mathrm{mL}$ and Baccharis dracunculifolia presented MIC value of $800 \mu \mathrm{g} / \mathrm{mL}$. The highest MIC values $(1,000 \mu \mathrm{g} / \mathrm{mL})$ were obtained from Senna macranthera and Artemisia absinthium. These MIC results were higher than $\mathrm{MIC}_{90}$ values against Staph. aureus that were observed in the present study (Caat $1-54 \geq 6.25 \mu \mathrm{g} / \mathrm{mL}$, and Caat P5-8 $\geq 100 \mu \mathrm{g} / \mathrm{mL})$.

Perini et al. (2014) evaluated the antimicrobial activity of 8 essential oils against Staph. aureus isolated from cows affected by clinical and subclinical mastitis. Cinnamomum cassia oil presented the best antimicrobial activity against Staph. aureus isolates (MIC $=0.4 \mu \mathrm{L} /$ $\mathrm{mL}$ ). Perini et al. (2014) observed that isolates of Staph aureus were inhibited at 10 different dilutions of Cymbopogon flexosus, Cymbopogon winterianus, and Salvia sclarea. Similarly, in the present study, we observed that Staph. aureus isolates were also inhibited at $8(0.096$, $0.19,0.39,0.78,1.56,3.12,6.25$, and $12.5 \mu \mathrm{g} / \mathrm{mL}$ ) of the 12 tested concentrations of Caat 1-54 crude extract. In fact, as mentioned herein, this variability of MIC values

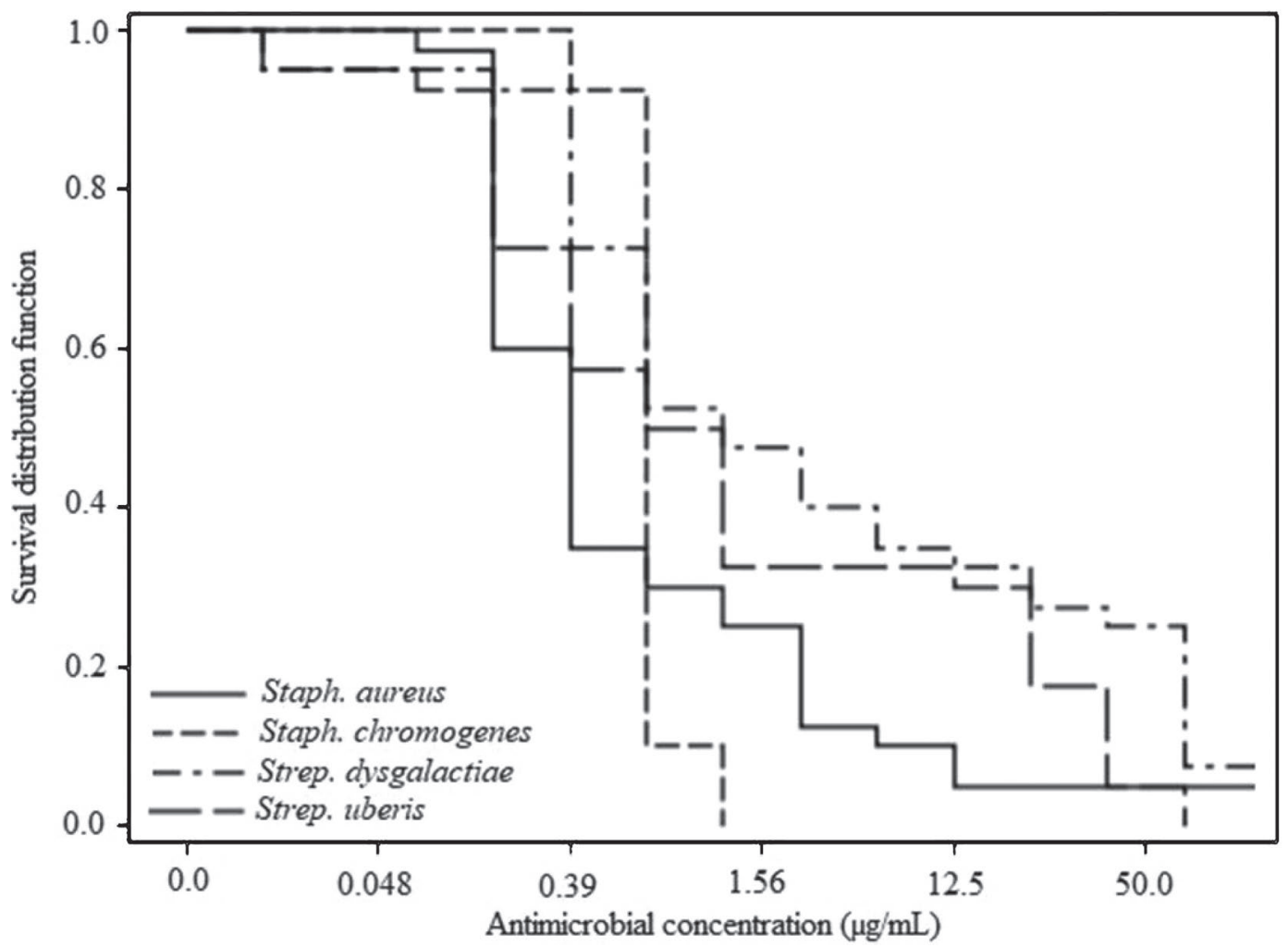

Figure 2. Kaplan-Meier survival curves of Caat 1-54 crude extract for Staphylococcus aureus, Staphylococcus chromogenes, Streptococcus dysgalactiae, and Streptococcus uberis isolated from clinical and subclinical bovine mastitis cases. 
for the inhibition of bacterial growth may be caused by the diversity of Staph. aureus strains (Smith et al., 2005; Costa et al., 2012). Furthermore, previous results suggest a bacterial growth inhibition from plants to treat bovine mastitis (Ananda Baskaran et al., 2009). Active compounds, such as trans-cinnamaldehyde, eugenol, carvacrol, and thymol, were evaluated against isolates obtained from clinical mastitis. Trans-cinnamaldehyde was the most efficient antimicrobial compound because it inhibited the growth of all tested pathogens (Staph. aureus, Escherichia coli, Strep. uberis, Streptococcus agalactiae, and Strep. dysgalactiae).

Ceftiofur is a third-generation cephalosporin antibiotic with broad-spectrum antimicrobial activity that is frequently used for the treatment of infectious diseases in dairy cows (Rajala-Schultz et al., 2004; Saini et al., 2012). For this reason, ceftiofur was used in the present study as a positive control. Previous studies evaluated the susceptibility of selected mastitis pathogens to ceftiofur using the agar dilution method and reported similar values of $\mathrm{MIC}_{50}(0.5 \mu \mathrm{g} / \mathrm{mL})$ and $\mathrm{MIC}_{90}(1.0$ $\mu \mathrm{g} / \mathrm{mL}$ ) for Staph. aureus obtained from clinical and subclinical mastitis (Oliveira et al., 2012; Cortinhas et al., 2013). Saini et al. (2012) described similar $\mathrm{MIC}_{50}$ and $\mathrm{MIC}_{90}(1 \mu \mathrm{g} / \mathrm{mL})$ to those reported by Oliveira et al. (2012) and Cortinhas et al. (2013). Ruegg et al. (2015) studied only Staph. aureus isolated from clinical mastitis and described that $\mathrm{MIC}_{50}$ and $\mathrm{MIC}_{90}$ of ceftiofur was $0.25 \mu \mathrm{g} / \mathrm{mL}$, which was lower than MIC (0.5 to $1.0 \mu \mathrm{g} / \mathrm{mL}$ ) described by Oliveira et al. (2012), Saini et al. (2012), and Cortinhas et al. (2013). However, in the present study, $\mathrm{MIC}_{50}$ and $\mathrm{MIC}_{90}$ values of ceftiofur against Staph. aureus isolates were higher than the results obtained $(0.25$ to $1.0 \mu \mathrm{g} / \mathrm{mL})$ in those studies (Oliveira et al., 2012; Saini et al., 2012; Cortinhas et al., 2013; Ruegg et al., 2015).

In the present study, $80 \%$ of Staph. aureus and $97.5 \%$ of Staph. chromogenes isolates were classified according to CLSI (2008) guidelines as intermediate, and we also classified some isolates (20\% of Staph. aureus and $2.5 \%$ of Staph. chromogenes) as resistant to ceftiofur. Likewise, in another Brazilian study that evaluated the susceptibility of CNS isolated from bovine mastitis, $75 \%$ of isolates were resistant to amoxicillin and $80 \%$ were resistant to penicillin (Freitas et al., 2005). In summary, the current higher percentage of ceftiofur resistance could be explained due to the uncontrolled use of antimicrobials for mastitis treatment in Brazilian dairy herds, as antimicrobials could be bought and used without a veterinary prescription.

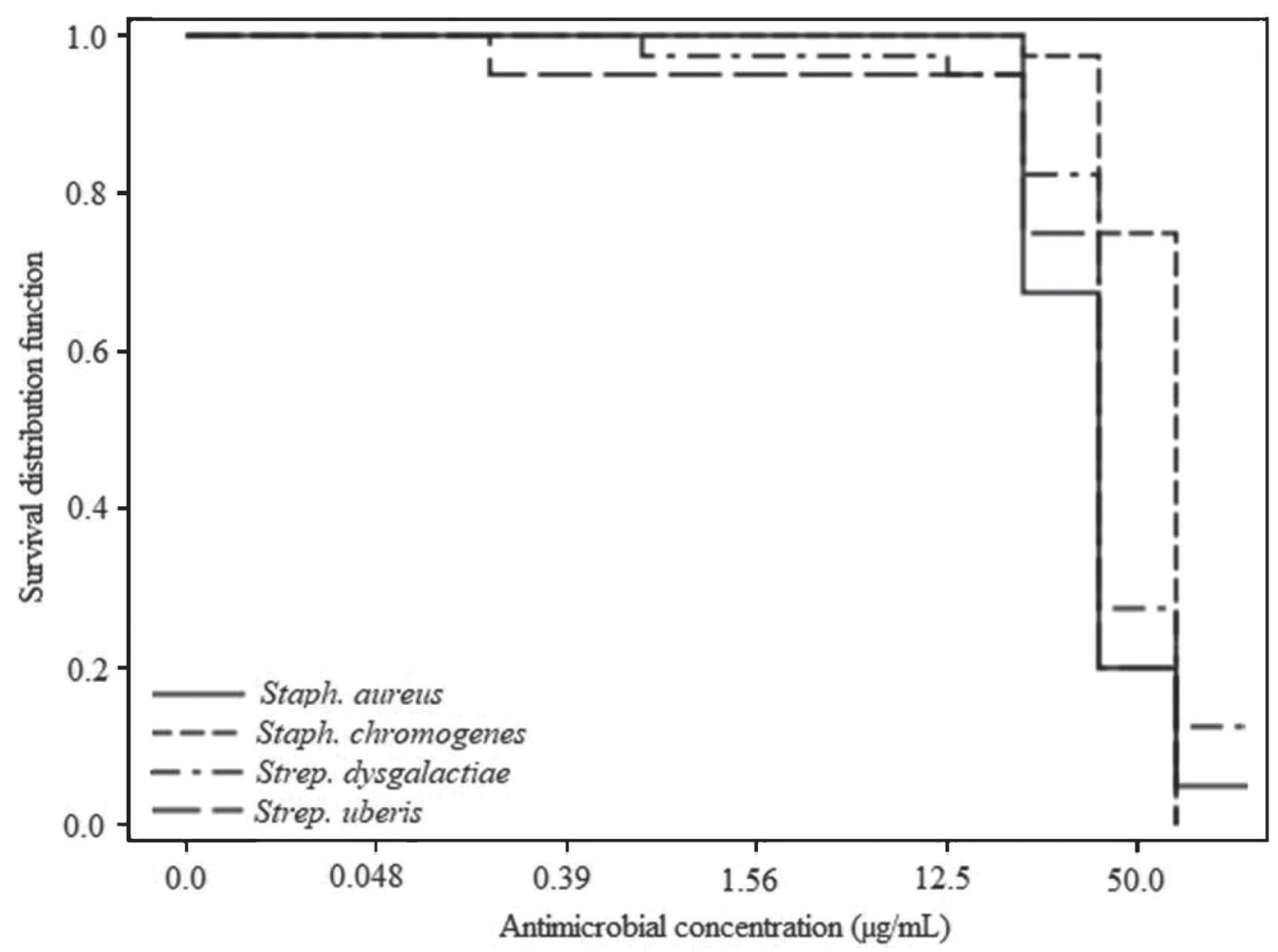

Figure 3. Kaplan-Meier survival curves of Caat P5-8 crude extract for Staphylococcus aureus, Staphylococcus chromogenes, Streptococcus dysgalactiae, and Streptococcus uberis isolated from clinical and subclinical bovine mastitis cases. 
The Caat 1-54 extract presented lower values of $\mathrm{MIC}_{50}$ and $\mathrm{MIC}_{90}$ for Staph. chromogenes than ceftiofur and Caat P5-8 extract. Both $\mathrm{MIC}_{50}$ and $\mathrm{MIC}_{90}$ presented the same values for each evaluated antimicrobial category because the inhibition of growth of isolates occurred more frequently in only 3 concentrations of the serial dilutions tested (ceftiofur $=3.12,6.25$, and $12.5 \mu \mathrm{g} / \mathrm{mL}$; Caat $1-54=0.39,0.78$, and $1.56 \mu \mathrm{g} / \mathrm{mL}$; Caat P5-8 = 25, 50, and $100 \mu \mathrm{g} / \mathrm{mL})$. Staphylococcus chromogenes is considered a minor pathogen causing subclinical mastitis because its inflammatory response at quarter level is lower (median values of 200,000 < $\mathrm{SCC} \leq 500,000$ cells $/ \mathrm{mL}$ ) than that caused by major pathogens (Staph. aureus, Strep. dysgalactiae, and Strep. uberis; Piepers et al., 2013; Tomazi et al., 2015). Nevertheless, it has been described that intramammary infections caused by Staph. chromogenes can increase SCC comparable to Staph. aureus (Supré et al., 2011), and this is the reason for the evaluation of the susceptibility of Staph. chromogenes to crude extracts in the present study.

Ceftiofur presented lower $\mathrm{MIC}_{50}(<0.048 \mu \mathrm{g} / \mathrm{mL})$ against Strep. dysgalactiae than Caat $1-54(\geq 1.56 \mu \mathrm{g} /$ $\mathrm{mL})$ and Caat P5-8 ( $\geq 50 \mu \mathrm{g} / \mathrm{mL})$. Furthermore, $\mathrm{MIC}_{90}$ of these 3 antimicrobials presented higher values $(>100$ $\mu \mathrm{g} / \mathrm{mL}$ for ceftiofur, Caat 1-54, and Caat P5-8) than $\mathrm{MIC}_{50}$. This result suggests that $\mathrm{MIC}_{90}$ of ceftiofur was 14 dilutions higher in relation to $\mathrm{MIC}_{50}$ (variation of $<0.048$ to $>100 \mu \mathrm{g} / \mathrm{mL}$ ). The $\mathrm{MIC}_{90}$ of Caat $1-54$ was 7 dilutions higher than $\mathrm{MIC}_{50}$ (variation of $\geq 1.56$ to $>100 \mu \mathrm{g} / \mathrm{mL}$ ) and $\mathrm{MIC}_{90}$ of Caat P5-8 was 3 dilutions higher in comparison to $\mathrm{MIC}_{50}$ (variation of $\geq 50$ to $>100 \mu \mathrm{g} / \mathrm{mL}$ ). In the present study, $\mathrm{MIC}_{50}$ of ceftiofur against Strep. dysgalactiae was $<0.048 \mu \mathrm{g} / \mathrm{mL}$, because bacterial growth inhibition was observed at the lowest concentration of antimicrobial tested. Because of this, it was not possible to precisely determine $\mathrm{MIC}_{50}$ for these isolates. Cortinhas et al. (2013) reported a similar value of $\mathrm{MIC}_{50}(0.03 \mu \mathrm{g} / \mathrm{mL})$, but a different value of $\mathrm{MIC}_{90}$ $(0.06 \mu \mathrm{g} / \mathrm{mL})$ for ceftiofur against Strep. dysgalactiae isolated from bovine mastitis when compared with the results of the present study.

Considering that all evaluated antimicrobials were tested under the same serial dilution, varying from 0.048 to100 $\mu \mathrm{g} / \mathrm{mL}$, ceftiofur presented higher in vitro antimicrobial activity against Strep. uberis than Caat 1-54 and Caat P5-8 crude extracts, as a lower concentration of ceftiofur was necessary to inhibit Strep. uberis isolates. Caat 1-54 presented higher antimicrobial activity against Strep. uberis clinical and subclini-

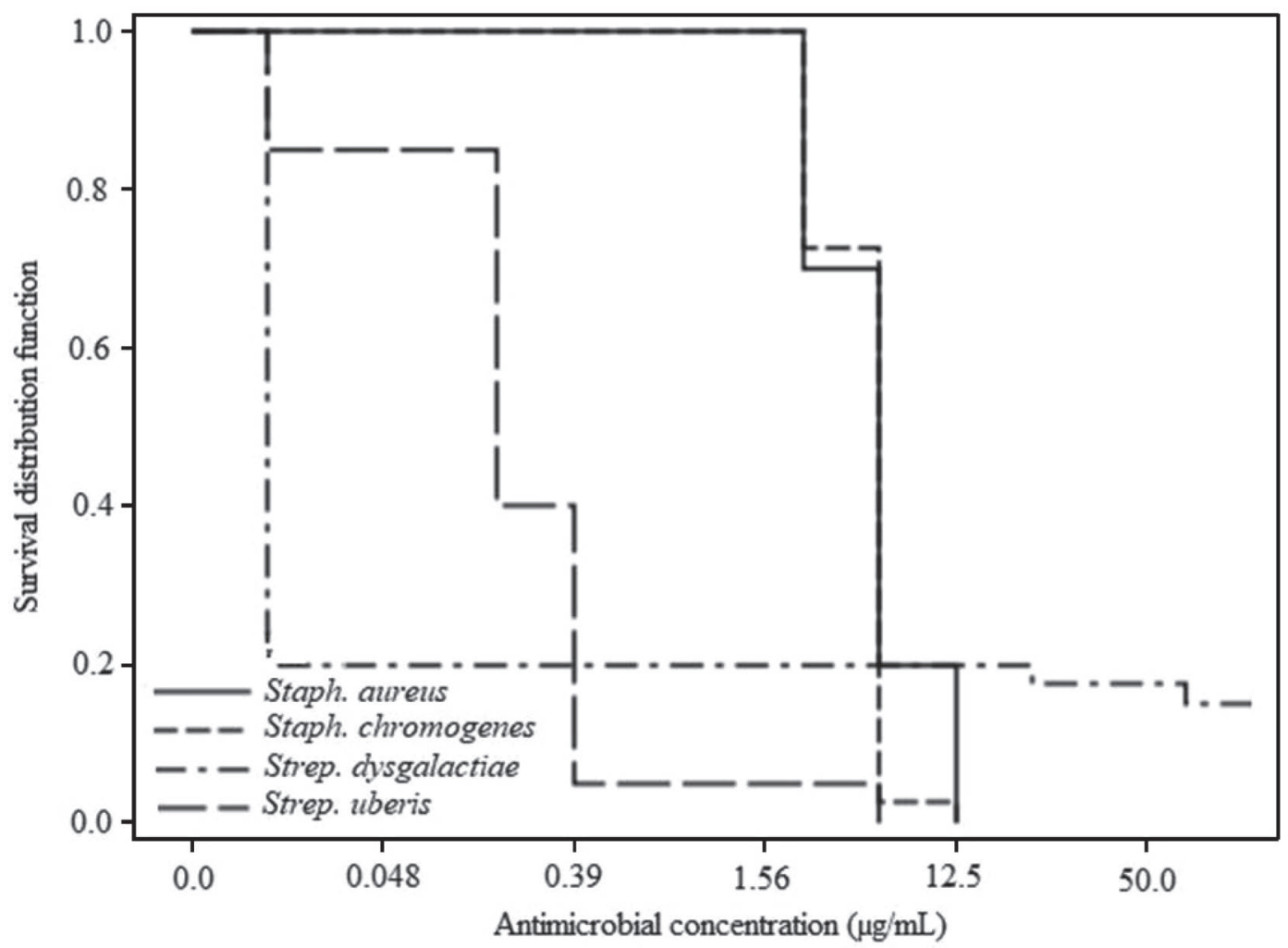

Figure 4. Kaplan-Meier survival curves of ceftiofur crude extract for Staphylococcus aureus, Staphylococcus chromogenes, Streptococcus dysgalactiae, and Streptococcus uberis isolated from clinical and subclinical bovine mastitis cases. 
cal mastitis due to lower $\mathrm{MIC}_{90}$ when compared with Caat P5-8 ( $\geq 50$ vs. $\geq 100 \mu \mathrm{g} / \mathrm{mL}$ ). However, Caat $1-54$ extract presented MIC values against Strep. uberis isolated from clinical and subclinical mastitis with a wide range between the evaluated dilutions $(<0.048$ to 100 $\mu \mathrm{g} / \mathrm{mL}$ ). The MIC results of different compounds with antimicrobial activity were not found for Strep. uberis for comparison with the results obtained in the present study. The $\mathrm{MIC}_{50}$ of ceftiofur against Strep. uberis isolated from clinical $(\geq 0.19 \mu \mathrm{g} / \mathrm{mL})$ and subclinical $(\geq 0.39 \mu \mathrm{g} / \mathrm{mL})$ mastitis were lower than the values described by Cortinhas et al. $\left(2013 ; \mathrm{MIC}_{50}\right.$ of $1 \mu \mathrm{g} / \mathrm{mL}$; $\mathrm{MIC}_{90}$ of $2 \mu \mathrm{g} / \mathrm{mL}$ ) and by Rajala-Schultz et al. (2004; MIC of $4 \mu \mathrm{g} / \mathrm{mL}$ ).

In this preliminary study, we observed that Caat 1-54 and Caat P5-8 crude extracts produced by actinomycetes from Caatinga biome presented in vitro antimicrobial activity against Staph. aureus, Staph. chromogenes, Strep. dysgalactiae, and Strep. uberis isolated from cases of bovine mastitis. Despite in vitro inhibition of bacterial growth by crude extracts, future studies should be undertaken to evaluate the pharmacokinetics and cytotoxicity of Caat 1-54 and Caat P5-8 on the mammary tissue before the in vivo testing. As Caat 1-54 and Caat P5-8 present desirable antimicrobial characteristics, both crude extracts might be a potential alternative in the developing products against mastitis-causing pathogens.

\section{ACKNOWLEDGMENTS}

The authors acknowledge Brazilian Federal Agency for Support and Evaluation of Graduate Education (CAPES, Brasília, DF, Brazil) and São Paulo Research Foundation (FAPESP, São Paulo, SP, Brazil, process. no.2016/22023-0) for the scholarship.

\section{REFERENCES}

Ananda Baskaran, S., G. W. Kazmer, L. Hinckley, S. M. Andrew, and K. Venkitanarayanan. 2009. Antibacterial effect of plant-derived antimicrobials on major bacterial mastitis pathogens in vitro. J. Dairy Sci. 92:1423-1429.

Barkema, H. W., Y. H. Schukken, and R. N. Zadoks. 2006. Invited review: The role of cow, pathogen, and treatment regimen in the therapeutic success of bovine Staphylococcus aureus mastitis. J. Dairy Sci. 89:1877-1895.

Barreiro, J. R., C. R. Ferreira, G. B. Sanvido, M. Kostrzewa, T. Maier, B. Wegemann, V. Bottcher, M. N. Eberlin, and M. V. dos Santos. 2010. Short communication: Identification of subclinical cow mastitis pathogens in milk by matrix-assisted laser desorption/ionization time-of-flight mass spectrometry. J. Dairy Sci. 93:5661-5667.

Bauermeister, A., T. D. Zucchi, and L. A. Moraes. 2016. Mass spectrometric approaches for the identification of anthracycline analogs produced by actinobacteria. J. Mass Spectrom. 51:437-445.

Chater, K. F., S. Biro, K. J. Lee, T. Palmer, and H. Schrempf. 2010. The complex extracellular biology of Streptomyces. FEMS Microbiol. Rev. 34:171-198.
CLSI (Clinical and Laboratory Standards Institute). 2008. Performance standards for antimicrobial disk and dilution susceptibility tests for bacterial isolated from animals. Approved Standard. (CLSI document M31-A3) 3rd ed. CLSI, Wayne, PA.

Cortinhas, C. S., L. Oliveira, C. A. Hulland, M. V. Santos, and P. L. Ruegg. 2013. Minimum inhibitory concentrations of cephalosporin compounds and their active metabolites for selected mastitis pathogens. Am. J. Vet. Res. 74:683-690.

Costa, G. M., L. V. Paiva, H. C. Figueiredo, A. R. Figueira, U. P. Pereira, and N. Silva. 2012. Population diversity of Staphylococcus aureus isolated from bovine mastitis in Brazilian dairy herds. Res. Vet. Sci. 93:733-735.

Cunha, M. N. C., N. M. V. Silva, M. F. S. Teixeira, R. A. Mota, J. L. Lima-Filho, T. S. Porto, and A. L. F. Porto. 2010. Actinomicetos produtores de inibidores de $\beta$-lactamases com atividade antimicrobiana frente a isolados de mastite bovina. Arq. Bras. Med. Vet. Zootec. 62:1312-1319.

de Oliveira, T. L., E. O. Lima, I. A. de Souza, and L. C. Z. Cornejo. 2010. Atividade antifúngica e cinética de morte microbiana de extratos obtidos de Streptomyces spp. isolados de solos paraibanos. Rev. Bras. Farmacogn. 20:60-64.

Diaz, M. A. N., C. C. Rossi, V. R. Mendonça, D. M. Silva, A. O. B. Ribon, A. P. Aguilar, and G. D. Muñoz. 2010. Screening of medicinal plants for antibacterial activities on Staphylococcus aureus strains isolated from bovine mastitis. Rev. Bras. Farmacogn. 20:724-728.

Drautz, H., W. Keller-Schierlein, and H. Zahner. 1975. Metabolic products of microorganisms, 149. Lysolipin I, a new antibiotic from Streptomyces violaceoniger (author's transl)]. Arch. Microbiol. 106:175-190.

Fitzgerald, J. R. 2012. Livestock-associated Staphylococcus aureus: Origin, evolution and public health threat. Trends Microbiol. 20:192-198.

Freitas, F. L. M., J. W. Pinheiro Jr., T. L. M. Stamford, S. S. A. Rabelo, D. R. Silva, V. M. V. Silveira-Filho, F. G. B. Santos, M. J. Sena, and R. A. Mota. 2005. Profile of in vitro antimicrobial susceptibility of coagulase-positive Staphylococcus isolated from milk from cows with mastitis in the rural area of Pernambuco State. Arq. Inst. Biol. (Sao Paulo) 72:171-177.

Hogan, J. S., R. N. Gonzalez, R. J. Harmon, S. C. Nickerson, S. P. Oliver, J. W. Pankey, and K. L. Smith. 1999. Laboratory Handbook on Bovine Mastitis. 2nd. National Mastitis Council Inc., Madison, WI.

Jagielski, T., E. Puacks, A. Lisowski, P. Siedlecki, W. Dudziak, J. Miedzobrodzki, and H. Krukowski. 2014. Short communication: Antimicrobial susceptibility profiling and genotyping of Staphylococcus aureus isolates from bovine mastitis in Poland. J. Dairy Sci. 97:6122-6128.

Kakinuma, S., H. Ikeda, S. Omura, and D. A. Hopwood. 1990. Biosynthesis of kalafungin in Streptomyces tanashiensis. J. Antibiot. (Tokyo) 43:391-396.

Liu, H., S. Li, L. Meng, L. Dong, S. Zhao, X. Lan, J. Wang, and N. Zheng. 2017. Prevalence, antimicrobial susceptibility, and molecular characterization of Staphylococcus aureus isolated from dairy herds in northern China. J. Dairy Sci. 100:8796-8803.

Makovec, J. A., and P. L. Ruegg. 2003. Results of milk samples submitted for microbiological examination in Wisconsin from 1994 to 2001. J. Dairy Sci. 86:3466-3472.

Oliveira, L., H. Langoni, C. Hulland, and P. L. Ruegg. 2012. Minimum inhibitory concentrations of Staphylococcus aureus recovered from clinical and subclinical cases of bovine mastitis. J. Dairy Sci. 95:1913-1920.

Perini, S., R. H. Piccoli, C. A. Nunes, F. R. P. Bruhn, D. A. C. Custodio, and G. M. Costa. 2014. Antimicrobial activity of essential oils against pathogens isolated from bovine mastitis. J. Nat. Prod. Plant Resour. 4:6-15.

Piepers, S., Y. H. Schukken, P. Passchyn, and S. De Vliegher. 2013. The effect of intramammary infection with coagulase-negative staphylococci in early lactating heifers on milk yield throughout first lactation revisited. J. Dairy Sci. 96:5095-5105. 
Pol, M., and P. L. Ruegg. 2007a. Relationship between antimicrobial drug usage and antimicrobial susceptibility of gram-positive mastitis pathogens. J. Dairy Sci. 90:262-273.

Pol, M., and P. L. Ruegg. 2007b. Treatment practices and quantification of antimicrobial drug usage in conventional and organic dairy farms in Wisconsin. J. Dairy Sci. 90:249-261.

Priya, M., B. Anandaraj, and T. Ganesan. 2015. Antimicrobial activity of estuarine Actinobacteria against selected human pathogens. Int. J. Curr. Microbiol. Appl. Sci. 4:120-125.

Rajala-Schultz, P. J., K. L. Smith, J. S. Hogan, and B. C. Love. 2004. Antimicrobial susceptibility of mastitis pathogens from first lactation and older cows. Vet. Microbiol. 102:33-42.

Rakshanya, U., J. Hema Shenpagam N, and D. Kanchana Devi. 2011. Antagonistic activity of actinomycetes isolates against human pathogen. J. Microbiol. Biotech. Res. 1:74-79.

Ruegg, P. L., L. Oliveira, W. Jin, and O. Okwumabua. 2015. Phenotypic antimicrobial susceptibility and occurrence of selected resistance genes in gram-positive mastitis pathogens isolated from Wisconsin dairy cows. J. Dairy Sci. 98:4521-4534.

Saini, V., J. T. McClure, D. Leger, G. P. Keefe, D. T. Scholl, D. W. Morck, and H. W. Barkema. 2012. Antimicrobial resistance profiles of common mastitis pathogens on Canadian dairy farms. J. Dairy Sci. 95:4319-4332.

Schmidt, T., M. M. Kock, and M. M. Ehlers. 2015. Diversity and antimicrobial susceptibility profiling of staphylococci isolated from bovine mastitis cases and close human contacts. J. Dairy Sci. 98:6256-6269.

Schukken, Y. H., J. Hertl, D. Bar, G. J. Bennett, R. N. Gonzalez, B. J. Rauch, C. Santisteban, H. F. Schulte, L. Tauer, F. L. Welcome, and Y. T. Grohn. 2009. Effects of repeated gram-positive and gram-negative clinical mastitis episodes on milk yield loss in Holstein dairy cows. J. Dairy Sci. 92:3091-3105.

Shi, L., H. M. Ge, S. H. Tan, H. Q. Li, Y. C. Song, H. L. Zhu, and R. X. Tan. 2007. Synthesis and antimicrobial activities of Schiff bases derived from 5-chloro-salicylaldehyde. Eur. J. Med. Chem. 42:558-564.

Smith, E. M., L. E. Green, G. F. Medley, H. E. Bird, and C. G. Dowson. 2005. Multilocus sequence typing of Staphylococcus aureus isolated from high-somatic-cell-count cows and the environment of an organic dairy farm in the United Kingdom. J. Clin. Microbiol. 43:4731-4736.

Supré, K., F. Haesebrouck, R. N. Zadoks, M. Vaneechoutte, S. Piepers, and S. De Vliegher. 2011. Some coagulase-negative Staphylococcus species affect udder health more than others. J. Dairy Sci. 94:2329-2340.

Taddei, A., M. J. Rodriguez, E. Marquez-Vilchez, and C. Castelli. 2006. Isolation and identification of Streptomyces spp. from Venezuelan soils: Morphological and biochemical studies. I. Microbiol. Res. 161:222-231.

Tomazi, T. J. L. Goncalves, J. R. Barreiro, M. A. Arcari, and M. V. Dos Santos. 2015. Bovine subclinical intramammary infection caused by coagulase-negative staphylococci increases somatic cell count but has no effect on milk yield or composition. J. Dairy Sci. 98:3071-3078.

Zhang, S., S. Piepers, R. Shan, L. Cai, S. Mao, J. Zou, T. Ali, S. De Vliegher, and B. Han. 2018. Phenotypic and genotypic characterization of antimicrobial resistance profiles in Streptococcus dysgalactiae isolated from bovine clinical mastitis in 5 provinces of China. J. Dairy Sci. 101:3344-3355. 